\title{
Selection of potential non-Sacharomyces probiotic yeasts from food origin by a step-by-step approach
}

\author{
Pilar Fernandez-Pacheco Rodríguez ${ }^{\mathrm{a}}$, María Arévalo-Villena ${ }^{\mathrm{a}, *}$, Isabel Zaparoli Rosa ${ }^{\mathrm{b}}$, \\ Ana Briones Pérez ${ }^{\mathrm{a}}$ \\ ${ }^{\text {a } F o o d ~ S c i e n c e ~ a n d ~ T e c h n o l o g y ~ D e p a r t m e n t, ~ C a s t i l l a-L a ~ M a n c h a ~ U n i v e r s i t y, ~ A v . ~ C a m i l o ~ J o s e ́ ~ C e l a ~ S / N, ~ E d i f i c i o ~ M a r i e ~ C u r i e, ~ C i u d a d ~ R e a l ~ 13071, ~ S p a i n ~}$ \\ ${ }^{\mathrm{b}}$ Microbiology Department, Universidade Estadual Paulista, Instituto de Biociências, Letras e Ciências Exatas - Ibilce Bairro: Jardim Nazareth, Rua Cristóvão Colombo, \\ São Paulo 15054-000, Brazil
}

\section{A R T I C L E I N F O}

\section{Keywords:}

Non-Saccharomyces

Probiotic yeasts

Gastrointestinal resistance

Auto-aggregation

Hydrophobicity

Biofilm

\begin{abstract}
A B S T R A C T
Due to healthcare is increasing in nowadays, the use of the commercial probiotics is in progress and each day they are more demanded. The challenge of this study is to identify yeast species for using as probiotic organisms. Thus, the research applied a step-by-step approach, to study the probiotic potential of non-Saccharomyces yeast strains. The 215 yeasts were isolated from different environments such as wineries, oil mills, brines cheeses, fermented vegetables and distilleries in previous works and were identified to strain level by RAPD-PCR technique resulting 108 different strains. A general screening was carried out to know the probiotic capability of the yeasts, following the next steps: study of the ability to resist and grow of the yeasts when they exposed to simulated in vitro digestion conditions and influence of time, temperature, $\mathrm{pH}$ and the presence of enzymes on the kinetic growth parameters (lag phase $(\lambda)$, generation time $(\mathrm{G})$, maximum $\mathrm{OD}\left(\mathrm{OD}_{\max }\right)$ and the specific growth rate constant $\left(\mu_{\max }\right)$ ). The results made possible the selection of the $23 \%$ of the strains and they were assayed for knowing their capability of self-aggregation and hydrophobicity. Biofilm formation capacity and viability after simulated sequential salivary-gastric-intestinal digestion were then studied for the 10 best strains. Statistical analyses were applied in each step to make the selection. The final results showed that two yeasts, $H$. osmophila and P. kudriavzevii, were the most promising strains.
\end{abstract}

\section{Introduction}

The Joint Food and Agricultural Organisation/World Health Organisation (2001) define probiotics as "live microorganisms, which when administered in adequate amounts, confer a health benefit on the host". However, Hill et al., 2014, published a document on the appropriate use and scope of the term probiotic for clinicians and consumers in differentiating the diverse products on the market. They conclude that this clarification is needed for facilitating the advances in probiotic research and for ensuring that their benefits, will be properly communicated to consumers and patients.

Due to healthcare is increasing in nowadays, the use of the commercial probiotics is in progress and each day are more demanded. Probiotics can be delivered as drugs or through food. However, they must survive the conditions of the upper gastrointestinal tract and then persist in the intestine, to provide beneficial effects to the host. Some of the potential mechanisms by which yeast protect the host against pathogens include immune system stimulation, the induction of growth of other probiotic organisms, degradation of bacterial toxins by the yeast's proteases and inhibition of pathogen adherence to gastrointestinal epithelial cells (Pérez-Sotelo et al., 2005; Arévalo-Villena, FernándezPacheco, Castillo, Bevilacqua, \& Briones, 2018).

Most probiotics currently commercialised are of bacterial origin because the majority of yeasts are particularly sensitive to the gastrointestinal tract conditions (Czerucka \& Rampal, 2002). The challenge is identifying yeast species that could be considered probiotic organisms. Some yeasts have shown resistance to the gastrointestinal conditions, which, together with their antibiotic resistance (Blehaut, Massot, Elmer, \& Levy, 1989), has made these eukaryotic organisms possible candidates for the development of new probiotics (Kourelis et al., 2010). For instance, the probiotic character of Saccharomyces cerevisiae var. boulardii, in particular, is well documented (Blehaut, Massot, Elmer, \& Levy, 1989; Czerucka \& Rampal, 2002; Klein, Elmer, McFarland, Surawicz, \& Levy, 1993). Perricone, Bevilacqua, Corbo, and Sinigaglia (2014) showed that this strain is able to survive at $\mathrm{pH} 2.5$ in the presence of bile salts, displays a hydrophobic property and shows biofilm

\footnotetext{
* Corresponding author.

E-mail addresses: Pilar.Fernandezpacheco@alu.uclm.es (P. Fernandez-Pacheco Rodríguez), Maria.Arevalo@uclm.es (M. Arévalo-Villena), Ana.Briones@uclm.es (A. Briones Pérez).
} 
formation. Some authors have found that other Saccharomyces sp. also possess these properties (Pennacchia, Blaiotta, Pepe, \& Villani, 2008; Pérez-Sotelo et al., 2005; Pizzolitto et al., 2012; Sourabh, Kanwar, \& Sharma, 2012).

Besides Saccharomyces sp., recent studies have demonstrated the existence of other yeast species with probiotic potential, such as Wickerhamomyces anomalus (García-Hernández et al., 2012), Candida krusei, Kluyveromyces marxianus, Candida rugosa and Trichosporon asahii (Pedersen, Owusu-Kwarteng, Thorsen, \& Jespersen, 2012) or Pichia kudriavzevii (Chelliah, Ramakrishnan, Prabhu, \& Antony, 2016). Psani and Kotzekidou (2006) found that a large majority of Torulaspora delbrueckii and Debaryomyces hansenii strains tolerated high bile salt concentrations and inhibited the growth of several pathogens (Psani \& Kotzekidou, 2006). Yeast strains Pichia membranaefaciens and Candida oleophila showed similar characteristics (Silva et al., 2011).

The aim of this research is to study the probiotic potential character of the non-Saccharomyces wild yeast strains isolated from different sources such as wineries, oil mills, brine cheeses, fermented vegetables and distilleries. For that tolerance to gastrointestinal conditions $\mathrm{pH}$, temperature, enzymes), auto-aggregation, hydrophobicity, biofilm formation and behavior after simulated sequential salivary-gastric-intestinal digestion were analysed. It is noted that each decision was made based on multifactorial statistical assay results.

\section{Materials and methods}

\subsection{Yeast strains}

A total of 215 yeasts belonging to various genera, such as Candida (10 species), Debaryomyces (3 species), Hanseniaspora (5 species), Kazachstania (2 species), Kluyveromyces (1 species), Lachancea (2 species), Metschnikowia (1 species), Ogataea (1 species), Pichia (9 species), Rhodotorula (1 species), Torulaspora (1 species), Yarrowia (1 species) and Zygosaccharomyces (3 species) were evaluated. The yeast strains are deposited in the culture collection of the Yeast Biotechnology Laboratory (University of Castilla-La Mancha, Spain) and maintained at $-80^{\circ} \mathrm{C}$ in a glycerol solution. All the strains were isolated in previous studies from food environment: winery, from white (Airen) or red (Cencibel) musts, at different stages of spontaneous fermentation (beginning or middle); oil mills from two different varieties (Arbequina and Cornicabra) being all of them from olive pastes and pomaces; brine chesses; different stages of vegetable fermentations and distillery plants sweet and fermented piquettes from ethanol production process (Barrajón, Arévalo-Villena, \& Briones, 2009; Ortiz, Barrajón, AalverBaffi, Arévalo-Villena, \& Briones, 2013; Romo Sánchez, Alves Baffi, Arévalo, Úbeda, \& Briones, 2010; Úbeda, Maldonado Gil, Chiva, Guillamón, \& Briones, 2014). As positive controls, a S. cerevisiae strain UCLM 3 with probiotic characteristics found by Arévalo-Villena et al. (2018) (control 1+) and a commercial probiotic S. cerevisiae var. boulardii strain (control 2+) were used.

For their use and before each assay, the strains were grown in YPD broth (Pronadisa-Conda) and incubated at $30^{\circ} \mathrm{C}$ for $48 \mathrm{~h}$ with a shaking incubator. The cell concentration was determined by enumeration of yeast cells, using a Thoma chamber. The cells were harvested by centrifugation at room temperature ( $5000 \mathrm{rpm}$ for $5 \mathrm{~min}$ ). After that, cells were washed with saline solution and the pellet was immediately use for the corresponding assay.

\subsection{Differentiation of non-Saccharomyces strains by random amplified polymorphic DNA polymerase chain reaction (RAPD-PCR)}

Molecular identification included PCR reactions of 5.8S rRNA region gene with ITS1 and ITS2 primers followed by restriction pattern analysis (RFLP) were used to identify of yeasts at specie level. It is well known that some microbial properties are strain-dependent, so, to optimise the work, an initial identification of the 215 yeasts mentioned above was made at the strain level. A cell pellet of each strain was treated with a zymolyase solution $(10 \mathrm{mg} / \mathrm{mL}$ zymolyase $20 \mathrm{~T}$ in $1.2 \mathrm{M}$ sorbitol buffer, $40 \mathrm{mM}$ sodium phosphate buffer, $\mathrm{pH} 7$ ). After incubation at $37^{\circ} \mathrm{C} / 30 \mathrm{~min}$ and $95^{\circ} \mathrm{C} / 5 \mathrm{~min}$, a cell lysate was obtained. RAPDPCR reaction was accomplished using primer R3 (5`ATGCAGCCAC3`) and $1 \mu \mathrm{L}$ of DNA in a final volume of $10 \mu \mathrm{L}$, according to the conditions established by Corte et al. (2005), and primer M13 (5 GAGGGTGGCG GTTCT3'), using $1.5 \mu \mathrm{L}$ of DNA in a final volume of $15 \mu \mathrm{L}$, under the conditions detailed by Padilla, Manzanares, and Belloch (2014). PCR amplification was performed in a Perkin - Elmer GeneAmp PCR System 2400. The amplified DNA was separated by electrophoresis in $2 \% \mathrm{w} / \mathrm{v}$ agarose gels and visualised by the gel Green $(6 \times)$.

\subsection{Growth kinetics under gastrointestinal conditions: preliminary probiotic screening}

All strains were exposed to the gastrointestinal conditions described by Arévalo-Villena et al. (2018). For the gastric conditions, 8 log CFU/ $\mathrm{mL}$ were inoculated in gastric solution (YPD containing $3 \mathrm{mg} / \mathrm{mL}$ pepsin in phosphate buffered saline, $\mathrm{pH}$ 2) and maintained at $37^{\circ} \mathrm{C} / 3 \mathrm{~h}$, under static conditions. Then, $10 \mu \mathrm{L}$ of this solution was transferred to an intestinal solution (YPD containing $0.5 \%$ bile salts and $1 \mathrm{mg} / \mathrm{mL}$ pancreatin in YPD broth, $\mathrm{pH} 8$ ) and incubated at $37^{\circ} \mathrm{C} / 22 \mathrm{~h}$. Cell growth in the intestinal solution was evaluated at $600 \mathrm{~nm}$, using an ELX808 Absorbance Microplate Reader (Bio-Tek Instruments, Vermont, USA). Measurements were taken every 20 min for $24 \mathrm{~h}$, with an agitation period of $15 \mathrm{~s}$ before reading.

Growth curves were obtained by plotting optical density (OD) versus time. Kinetic parameters including lag phase $(\lambda)$, generation time (G), maximum $\mathrm{OD}\left(\mathrm{OD}_{\max }\right)$ and the specific growth rate constant $\left(\mu_{\max }\right)$ were calculated, using the model described by Warringer and Blomberg (2003).

\subsection{Auto-aggregation capability}

The method proposed by Bautista-Gallego et al. (2013), with slight modifications, was adopted to investigate the auto-aggregation. Briefly, the washed cell pellets from overnight cultures were resuspended in an equal volume of saline solution $(0.9 \% \mathrm{NaCl})$ and incubated at $37^{\circ} \mathrm{C} /$ $30 \mathrm{~min}$. Absorbance at $600 \mathrm{~nm}$ (Jasco V-530 spectrophotometer) of an aliquot taken from the upper suspension, both at time zero (inoculation time) $\left(\mathrm{A}_{0}\right)$ and $30 \mathrm{~min}\left(\mathrm{~A}_{\mathrm{F}}\right)$ were measured. The auto-aggregation percentage was calculated as follows:

$\left[1-\left(\mathrm{A}_{\mathrm{F}} / \mathrm{A}_{0}\right] \times 100 \%\right.$

\subsection{Cell surface hydrophobicity}

Hydrophobicity assays were performed according to the method described by Bautista-Gallego et al. (2013), with modifications. Cell biomass was suspended in $10 \mathrm{~mL} \mathrm{KNO}_{3}(0.1 \mathrm{M})$ and absorbance at $600 \mathrm{~nm}$ was measured $\left(\mathrm{A}_{0}\right)$. Then, $3 \mathrm{~mL}$ toluene and xylene, respectively, were added to independent samples. After incubation at $37^{\circ} \mathrm{C}$ $\mathrm{min} / 60 \mathrm{~min}$, without shaking, the absorbance of the interphase was measured $\left(A_{F}\right)$. The hydrophobicity percentage was calculated as follows:

$\left[1-\left(\mathrm{A}_{\mathrm{F}} / \mathrm{A}_{0}\right)\right] \times 100 \%$

\subsection{Biofilm formation}

Biofilm formation was monitored as described by Speranza, Corbo, and Sinigaglia (2011), with modifications. A population of $6 \log$ CFU/ $\mathrm{mL}$ was inoculated in flasks with YPD and a sterile glass slide, and incubated at $37^{\circ} \mathrm{C}$. After $24 \mathrm{~h}$, each slide was aseptically removed, washed with sterile water and introduced into a flask containing $45 \mathrm{~mL}$ of 
sterile saline solution. The samples were sonicated (Ultrasonic processor, Qsonica) for $3 \mathrm{~min}$ at a constant $20 \%$ power, to suspend the biofilm adhered to the surface slide. Cell viability was determined after seeding of the cells using an Eddy Jet 2 spiral seeding machine (IUL Instruments). Results were expressed as $\log \mathrm{CFU} / \mathrm{cm}^{2}$.

\subsection{Study of viability and biofilm formation of yeasts after sequential simulated digestion}

Sequential simulated digestion was performed as reported by Armando et al. (2012), with the modifications proposed by Kos, Šušković, Goreta, and Matošić (2000) and Priya, Vijayalakshmi, and Raichur (2011). For the salivary conditions, a population of $8 \log \mathrm{CFU} /$ $\mathrm{mL}$ was suspended in a sterile electrolyte solution containing $0.22 \mathrm{~g} / \mathrm{L}$ $\mathrm{CaCl}_{2}, 6.2 \mathrm{~g} / \mathrm{L} \mathrm{NaCl}, 2.2 \mathrm{~g} / \mathrm{L} \mathrm{KCl}, 1.2 \mathrm{~g} / \mathrm{L} \mathrm{NaHCO}_{3}$ (Sigma-Aldrich) and $100 \mathrm{mg} / \mathrm{L}$ lysozyme (pH 6.5), and incubated at $300 \mathrm{rpm} / 37^{\circ} \mathrm{C} / 5 \mathrm{~min}$. After exposure to salivary conditions, cells were harvested by centrifugation $\left(5000 \mathrm{rpm} / 25^{\circ} \mathrm{C} / 15 \mathrm{~min}\right)$, suspended in simulated gastric fluid $(0.9 \% \mathrm{NaCl}$, buffered to $\mathrm{pH} 2.0$ and containing $3 \mathrm{~g} / \mathrm{L}$ pepsin [porcine gastric mucosal, Sigma-Aldrich]) and then, incubated at $37^{\circ} \mathrm{C} /$ $2 \mathrm{~h}$ with shaking $(300 \mathrm{rpm})$. After gastric simulation, cells were harvested by centrifugation $\left(5000 \mathrm{rpm} / 25^{\circ} \mathrm{C} / 15 \mathrm{~min}\right)$, and suspended in simulated intestinal fluid at $37^{\circ} \mathrm{C} / 4 \mathrm{~h}$ at $300 \mathrm{rpm}$, using an orbital shaker. The intestinal fluid was prepared by adding $1 \mathrm{~g} / \mathrm{L}$ pancreatin (porcine pancreas, Sigma-Aldrich) and $3 \mathrm{~g} / \mathrm{L}$ bile extract (porcine bile extract, Sigma-Aldrich) to a solution at $\mathrm{pH} 8$, containing $6.5 \mathrm{~g} / \mathrm{L} \mathrm{NaCl}$, $0.835 \mathrm{~g} / \mathrm{L} \mathrm{KCl}, 0.22 \mathrm{~g} / \mathrm{L} \mathrm{CaCl}_{2}$ and $1.386 \mathrm{~g} / \mathrm{L} \mathrm{NaHCO}_{3}$.

Before and after sequential simulated digestion, the loss of viability was evaluated by plate counting, and biofilm formation by the procedure described in section 2.6.

Experiments detailed from between Sections 2.3 to 2.7 were carried out by quadruplicate.

\subsection{Statistical analysis}

Analysis of variance (ANOVA) and Duncan's test were applied to study the significant differences between the parameters found for each strain ( $\mathrm{p}<0.05)$. Correlations among the variables were identified by principal component analysis (PCA). All data analysis was performed with Excel 2013 (Microsoft Corporation) and SPSS (IBM SPSS Statistics 20).

\section{Results and discussion}

\subsection{Differentiation of non-Saccharomyces strains by random amplified polymorphic DNA polymerase chain reaction (RAPD-PCR)}

Molecular techniques have been successfully applied by several authors to identify the yeast biodiversity in diverse environments, not only for species identification, but also for strains identification (Andrighetto, Psomas, Tzanetakis, Suzzi, \& Lombardi, 2000; Grando, Ubeda, \& Briones, 1994; Guillamón \& Barrio, 2017; Suzzi et al., 2000; Úbeda, Maldonado Gil, Chiva, Guillamón, \& Briones, 2014), due to the fact that probiotic activity it is associated to strain-level.

In the current study, isolates from the same yeast species showed different genetic polymorphisms that were effectively differentiated by RAPD-PCR. Consequently, the 215 original isolates were differentiated into 108 strains. Table 1 shows the species, number of isolates and number of strains identified by RAPD-PCR, as well as the nomenclature assigned to each strain.

\subsection{Survival in simulated gastrointestinal digestion}

The 108 non-Saccharomyces strains were evaluated to verify their capacity to survive a simulated gastrointestinal process, and their growth kinetic parameters were obtained. For a microorganism to be considered as possessing potential probiotic character, it must arrive viable and functional in the large intestine. Hence, for initial discrimination, all yeasts with generation times $\geq 22 \mathrm{~h}$ were discarded (Dunne et al., 2001). Twenty-two hours was chosen as the cut-off value because this is the usual time required for the total gastrointestinal transit. In all, 25 strains ( $23 \%$ of the total) displayed a generation time $<22 \mathrm{~h}$ (Table 2). The remaining strains either did not grow at $37^{\circ} \mathrm{C}$ or did not tolerate acid pHs. Thus, the 25 possible candidate strains were further investigated by additional probiotic tests.

One factor ANOVA and Duncan's test was performed to identify the strains presenting the best experimental results. These tests indicated that for the lag phase $(\lambda)(\alpha=0.05 ; F=19.22 ; p=0.00)$, the best strain belonged to subset $1, C$. pararugosa (1231), with $\lambda$ of $0.15 \mathrm{~h}$. This was followed by subset 2, corresponding to strains belonging to $H$. valbyensis (1094), K. thermotolerans (1039), P. anomala (1082, 1090), M. pulcherrima (1012), P. kudriavzevii (1003, 1075), C. vini (1063), Lachancea sp. (1146) that had $\lambda$ by 4,40-6, 45 and, also, the commercial probiotic (control $2+$ ). Moreover, in subset 3, strains $H$. osmophila (1056), K. thermotolerans (1167), Lachancea sp. (1148) and $P$. kudriavzevii (1200) proved relevant, with $\lambda$ ranging from $6.98-7.30 \mathrm{~h}$. All other stains showed $\lambda>7.30 \mathrm{~h}$.

For the generation and rate parameters $(\alpha=0.05 ; \mathrm{F}=8.34$; $\mathrm{p}=0.00$ ), the strains that presented the best values, were $K$. thermotolerans (1167), Lachancea sp. (1148), H. osmophila (1056), Z. fermentati (1134), P. kudriavzevii (1200), Z. fermentati (1142), Z. bailii (1213) and Lachancea (1146), besides control $1+$. Moreover, these strains had higher growth rates than the commercial yeast. Finally, for the parameter $\mathrm{OD}_{\max },(\alpha=0.05 ; \mathrm{F}=9.41 ; \mathrm{p}=0.00)$ the strains with the best values were $H$. osmophila (1056), Lachancea (1148), T. delbrueckii (1055), Z. fermentati (1134), Lachancea (1146), P. kudriavzevii (1200), P. Caribbica (1135), P. kudriavzevii (1003), K. thermotolerans (1167), Z. fermentati (1187), as well as the controls (Table 2).

Considering the various parameters evaluated, strain Lachancea (1146) was the only one within the first two subsets that revealed the best generation, being, therefore, the one with the best kinetic characteristics, followed by $H$. osmophila (1056), Lachancea (1148), K. thermotolerans (1167) and P. kudriavzevii (1200). PCA verified these results (Fig. 1 and Table 3), where the five strains with the better aptitudes were included in the indicated zone. Moreover, these strains performed better than the controls. As expected, the parameters $\mu_{\max }$ and $\mathrm{OD}_{\max }$ presented values directly proportional among the best strains.

Other authors showed good results for W. anomalus (GarcíaHernández et al., 2012), P. kudriavzevii that tolerated physiological concentrations of bile salts, pepsin and pancreatin (Chelliah, Ramakrishnan, Prabhu, \& Antony, 2016) or a large number of T. delbrueckii and $D$. hansenii strains tolerated high bile salt concentrations (Psani \& Kotzekidou, 2006).

\subsection{Auto-aggregation assays}

The ability to adhere to epithelial cells and mucosal surfaces and, thereby, decrease or prevent the colonisation of pathogens has been suggested to be an important property of many probiotic strains (Vine et al., 2004). In most instances, aggregation ability was associated with cell adherence properties (Boris, Suárez, \& Barbés, 1997). Cell aggregation between microorganisms of the same strain (auto-aggregation) or between different strains (coaggregation) is of considerable importance in several ecological niches. Recent studies have demonstrated that there are many yeast strains with very high auto-aggregation rates (Arévalo-Villena et al., 2018; Binetti, Carrasco, Reinheimer, \& Suárez, 2013; Chelliah, Ramakrishnan, Prabhu, \& Antony, 2016).

In this research, the controls and the 25 strains identified from the initial screening tests as potential probiotic candidates were tested for their ability to self-aggregate (Table 4). The auto-aggregation percentages were highly variable, ranging from $3.85-64.43 \%$. H. osmophila 
Table 1

Strains of each specie, its nomenclature and source of isolation.

\begin{tabular}{|c|c|c|c|c|c|c|c|}
\hline Species & I & St & Nomenclature & Species & I & St & Nomenclature \\
\hline Candida lactis-condensi & 4 & 2 & $1113^{\mathrm{D}}, 1115^{\mathrm{D}}$ & Kluyveromyces thermotolerans & 12 & 6 & $1007^{\mathrm{W}}, 1039^{\mathrm{W}}, 1093^{\mathrm{D}}, 1109^{\mathrm{D}}, 1167^{\mathrm{V}}, 1186^{\mathrm{W}}$ \\
\hline C. ethanolica & 4 & 3 & $1099^{\mathrm{D}}, 1104^{\mathrm{D}}, 1111^{\mathrm{D}}$ & Lachancea sp. & 4 & 2 & $1146^{\mathrm{M}}, 1148^{\mathrm{M}}$ \\
\hline C. apícola & 8 & 8 & $\begin{array}{l}1054^{\mathrm{w}}, 1064^{\mathrm{w}}, 1065^{\mathrm{w}}, 1066^{\mathrm{w}}, 1067^{\mathrm{w}}, 1068^{\mathrm{w}}, \\
1070^{\mathrm{w}}, 1071^{\mathrm{w}}\end{array}$ & L. thermotolerans & 1 & 1 & $1189^{\mathrm{M}}$ \\
\hline C. diddensiae & 1 & 1 & $1154^{\mathrm{M}}$ & Metschnikowia pulcherrima & 5 & 4 & $1002^{\mathrm{W}}, 1004^{\mathrm{W}}, 1005^{\mathrm{W}}, 1012^{\mathrm{W}}$ \\
\hline C. pararugosa & 5 & 3 & $1228^{\mathrm{C}}, 1231^{\mathrm{C}}, 1237^{\mathrm{C}}$ & Ogataea polymorpha & 1 & 1 & $1087^{\mathrm{D}}$ \\
\hline C. sake & 1 & 1 & $1107^{\mathrm{D}}$ & Pichia anomala & 6 & 3 & $1082^{\mathrm{D}}, 1089^{\mathrm{D}}, 1090^{\mathrm{D}}$ \\
\hline Candida sp. & 2 & 2 & $1151^{\mathrm{M}}, 1152^{\mathrm{M}}$ & P. galeiformes & 7 & 5 & $1081^{\mathrm{D}}, 1101^{\mathrm{D}}, 1102^{\mathrm{D}}, 1110^{\mathrm{D}}, 1112^{\mathrm{D}}$ \\
\hline C. stellata & 3 & 2 & $1016^{\mathrm{W}}, 1003^{\mathrm{W}}$ & P. holstii & 6 & 3 & $1169^{\mathrm{M}}, 1176^{\mathrm{M}}, 1188^{\mathrm{M}}$ \\
\hline C. thermophila & 1 & 1 & $1179^{\mathrm{M}}$ & P. caribbica & 14 & 3 & $1135^{\mathrm{M}}, 1162^{\mathrm{M}}, 1181^{\mathrm{M}}$ \\
\hline C. vini & 1 & 1 & $1063^{\mathrm{W}}$ & P. galeiformes & 10 & 1 & $1081^{\mathrm{D}}$ \\
\hline Debaryomyces hansenii & 8 & 5 & $1001^{\mathrm{C}}, 1225^{\mathrm{C}}, 1235^{\mathrm{C}}, 1236^{\mathrm{C}}, 1240^{\mathrm{C}}$ & P. kudriavzevii & 12 & 5 & $1003^{\mathrm{W}}, 1075^{\mathrm{D}}, 1084^{\mathrm{D}}, 1085^{\mathrm{D}}, 1200^{\mathrm{W}}$ \\
\hline D. pseudopolymorphus & 1 & 1 & $1072^{\mathrm{W}}$ & P. membranaefaciens & 8 & 3 & $1006^{\mathrm{W}}, 1019^{\mathrm{w}}, 1091^{\mathrm{D}}$ \\
\hline D. polymorphus & 1 & 1 & $1053^{\mathrm{W}}$ & P. mississippiensis & 2 & 1 & $1091^{\mathrm{D}}$ \\
\hline Hanseniaspora meyery & 1 & 1 & $1079^{\mathrm{D}}$ & P. occidentalis & 8 & 4 & $1203^{\mathrm{V}}, 1206^{\mathrm{V}}, 1208^{\mathrm{V}}, 1212^{\mathrm{V}}$ \\
\hline H. osmophila & 15 & 5 & $1056^{\mathrm{D}}, 1076^{\mathrm{D}}, 1094^{\mathrm{D}}, 1117^{\mathrm{D}}, 1118^{\mathrm{D}}$ & Rhodotorula mucilaginosa & 2 & 3 & $1017^{\mathrm{w}}, 1047^{\mathrm{W}}, 1229^{\mathrm{C}}$ \\
\hline H. valbyensis & 1 & 1 & $1077^{\mathrm{D}}$ & Torulaspora delbrueckii & 17 & 4 & $1018^{\mathrm{w}}, 1055^{\mathrm{w}}, 1073^{\mathrm{D}}, 1192^{\mathrm{w}}$ \\
\hline H. guillermondii & 4 & 2 & $1035^{\mathrm{D}}, 1199^{\mathrm{D}}$ & Yarrowia lipolitica & 2 & 1 & $1222^{\mathrm{C}}$ \\
\hline H. uvarum & 8 & 5 & $1032^{\mathrm{D}}, 1033^{\mathrm{D}}, 1034^{\mathrm{D}}, 1083^{\mathrm{D}}, 1096^{\mathrm{D}}$ & Zygosaccharomyces fermentati & 18 & 7 & $\begin{array}{l}1061^{\mathrm{w}}, 1086^{\mathrm{D}}, 1134^{\mathrm{w}}, 1142^{\mathrm{w}}, 1157^{\mathrm{w}}, 1171^{\mathrm{w}}, \\
1187^{\mathrm{w}}\end{array}$ \\
\hline Kazachstania exigua & 2 & 1 & $1220^{\mathrm{W}}$ & Z. bailii & 4 & 3 & $1098^{\mathrm{D}}, 1213^{\mathrm{V}}, 1214^{\mathrm{V}}$ \\
\hline K. unispora & 4 & 1 & $1216^{\mathrm{V}}$ & Z. florentinus & 1 & 1 & $1183^{\mathrm{M}}$ \\
\hline
\end{tabular}

I: number of isolates; St: number of strains.

C: brine cheese; D: distillery; V: fermented vegetables; M: oil mill; W: Winery.

Table 2

Kinetic parameters obtained for strains with generation times $(G)<22 \mathrm{~h}$.

\begin{tabular}{|c|c|c|c|c|c|}
\hline Species & Strain nomenclature & $\lambda(\mathrm{h})$ & $\mu(1 / \mathrm{h})$ & G (h) & $\mathrm{OD}_{\max }(\mathrm{nm})$ \\
\hline Control 1+ & 3 & $8.75 \pm 1.25^{\mathrm{fghi}}$ & $0.16 \pm 0.05^{\mathrm{hijkl}}$ & $1.99 \pm 0.47^{\mathrm{a}}$ & $1.37 \pm 0.13^{\mathrm{i}}$ \\
\hline Control 2+ & 24 & $5.40 \pm 0.73^{\mathrm{bcd}}$ & $0.09 \pm 0.03^{\text {bcdef }}$ & $4.18 \pm 2.84^{b c}$ & $1.05 \pm 0.47^{\text {defghi }}$ \\
\hline P. kudriavzevii & 1003 & $6.32 \pm 0.16^{\text {bcdef }}$ & $0.10 \pm 0.03^{\text {cdefgh }}$ & $3.26 \pm 0.89^{\mathrm{ab}}$ & $1.07 \pm 0.21^{\text {defghi }}$ \\
\hline M. pulcherrima & 1012 & $5.55 \pm 4.75^{\mathrm{bcd}}$ & $0.09 \pm 0.00^{\text {bcdefg }}$ & $3.23 \pm 0.10^{\mathrm{ab}}$ & $0.82 \pm 0.16^{\mathrm{bcde}}$ \\
\hline P. membranaefaciens & 1019 & $14.30 \pm 1.28^{1 \mathrm{~m}}$ & $0.08 \pm 0.02^{\mathrm{abcde}}$ & $3.84 \pm 1.00^{\mathrm{ab}}$ & $0.92 \pm 0.28^{\mathrm{bcdef}}$ \\
\hline K. thermotolerans & 1039 & $5.13 \pm 1.04^{\mathrm{bc}}$ & $0.10 \pm 0.01^{\text {cdefgh }}$ & $2.89 \pm 0.18^{\mathrm{ab}}$ & $1.00 \pm 0.17^{\text {cdefgh }}$ \\
\hline T. delbrueckii & 1055 & $11.68 \pm 1.66^{\mathrm{jk}}$ & $0.15 \pm 0.07^{\text {fghijk }}$ & $2.38 \pm 1.07^{\mathrm{ab}}$ & $1.31 \pm 0.11^{\mathrm{ghi}}$ \\
\hline H. osmophila & 1056 & $6.98 \pm 0.35^{\text {cdefg }}$ & $0.21 \pm 0.02^{\mathrm{k} 1}$ & $1.46 \pm 0.17^{\mathrm{a}}$ & $1.38 \pm 0.04^{\mathrm{i}}$ \\
\hline C. vini & 1063 & $6.20 \pm 0.50^{\text {bcde }}$ & $0.08 \pm 0.02^{\text {bcde }}$ & $3.78 \pm 0.93^{\mathrm{ab}}$ & $0.72 \pm 0.30^{\mathrm{bcd}}$ \\
\hline P. kudriavzevii & 1075 & $6.15 \pm 0.00^{\text {bcde }}$ & $0.11 \pm 0.01^{\text {defghi }}$ & $2.64 \pm 0.20^{\mathrm{ab}}$ & $0.97 \pm 0.15^{\text {bcdefg }}$ \\
\hline P. galeiforms & 1081 & $12.02 \pm 0.75^{\mathrm{k}}$ & $0.04 \pm 0.01^{\mathrm{abc}}$ & $7.93 \pm 2.02^{\mathrm{d}}$ & $0.80 \pm 0.45^{\mathrm{bcde}}$ \\
\hline P. anomala & 1082 & $5.15 \pm 0.00^{\mathrm{bc}}$ & $0.09 \pm 0.02^{\text {bcdef }}$ & $3.44 \pm 0.53^{\mathrm{ab}}$ & $0.93 \pm 0.18^{\mathrm{bcdef}}$ \\
\hline O. polymorpha & 1087 & $8.15 \pm 0.00^{\mathrm{efgh}}$ & $0.05 \pm 0.01^{\mathrm{abcd}}$ & $6.43 \pm 1.34^{\mathrm{cd}}$ & $0.67 \pm 0.45^{\mathrm{bc}}$ \\
\hline P. anomala & 1090 & $5.30 \pm 3.23^{\mathrm{bcd}}$ & $0.16 \pm 0.04^{\mathrm{ghijk}}$ & $1.97 \pm 0.53^{\mathrm{a}}$ & $0.93 \pm 0.29^{\mathrm{bcdef}}$ \\
\hline H. osmophila & 1094 & $4.40 \pm 0.50^{\mathrm{b}}$ & $0.13 \pm 0.04^{\text {efghij }}$ & $2.59 \pm 0.93^{\mathrm{ab}}$ & $0.83 \pm 0.04^{\text {bcde }}$ \\
\hline C. sake & 1107 & $9.35 \pm 3.01^{\mathrm{ghij}}$ & $0.03 \pm 0.01^{\mathrm{ab}}$ & $12.64 \pm 5.86^{\mathrm{e}}$ & $0.81 \pm 0.44^{\mathrm{bcde}}$ \\
\hline Z. fermentati & 1134 & $10.88 \pm 0.85^{\mathrm{ijk}}$ & $0.20 \pm 0.01^{\mathrm{kl}}$ & $1.51 \pm 0.11^{\mathrm{a}}$ & $1.29 \pm 0.03^{\mathrm{fghi}}$ \\
\hline P. caribbica & 1135 & $9.48 \pm 0.83^{h i j}$ & $0.15 \pm 0.01^{\text {fghijk }}$ & $1.97 \pm 0.07^{\mathrm{a}}$ & $1.16 \pm 0.15^{\text {efghi }}$ \\
\hline Z. fermentati & 1142 & $9.48 \pm 0.47^{\mathrm{hij}}$ & $0.17 \pm 0.02^{\mathrm{ijkl}}$ & $1.74 \pm 0.16^{\mathrm{a}}$ & $0.61 \pm 0.04^{b}$ \\
\hline Lachancea sp. & 1146 & $6.45 \pm 0.00^{\text {bcdef }}$ & $0.17 \pm 0.13^{\mathrm{ijkl}}$ & $1.74 \pm 0.14^{\mathrm{a}}$ & $1.20 \pm 0.04^{\mathrm{fghi}}$ \\
\hline Lachancea sp. & 1148 & $7.30 \pm 0.17^{\text {cdefgh }}$ & $0.22 \pm 0.01^{\mathrm{kl}}$ & $1.46 \pm 0.45^{\mathrm{a}}$ & $1.35 \pm 0.07^{\mathrm{hi}}$ \\
\hline Candida sp. & 1151 & $15.80 \pm 4.74^{\mathrm{m}}$ & $0.02 \pm 0.01^{\mathrm{a}}$ & $18.57 \pm 6.01^{f}$ & $0.03 \pm 0.01^{\mathrm{a}}$ \\
\hline K. thermotolerans & 1167 & $7.15 \pm 0.00^{\text {cdefgh }}$ & $0.23 \pm 0.01^{\mathrm{kl}}$ & $1.31 \pm 0.03^{\mathrm{a}}$ & $1.04 \pm 0.07^{\text {defghi }}$ \\
\hline Z. fermentati & 1187 & $7.80 \pm 1.76^{\text {defgh }}$ & $0.12 \pm 0.02^{\text {defghi }}$ & $2.67 \pm 0.41^{\mathrm{ab}}$ & $1.06 \pm 0.06^{\text {defghi }}$ \\
\hline P. kudriavzevii & 1200 & $7.33 \pm 1.17^{\text {cdefgh }}$ & $0.19 \pm 0.11^{\mathrm{jkl}}$ & $2.43 \pm 1.80^{\mathrm{ab}}$ & $1.12 \pm 0.23^{\text {efghi }}$ \\
\hline Z. bailii & 1213 & $12.81 \pm 0.58^{\mathrm{k} 1}$ & $0.17 \pm 0.01^{\mathrm{ijkl}}$ & $1.73 \pm 0.12^{\mathrm{a}}$ & $0.94 \pm 0.14^{\text {bcdef }}$ \\
\hline C. pararugosa & 1231 & $0.15 \pm 0.00^{\mathrm{a}}$ & $0.04 \pm 0.00^{\mathrm{abc}}$ & $8.21 \pm 0.36^{d}$ & $0.20 \pm 0.05^{\mathrm{a}}$ \\
\hline
\end{tabular}

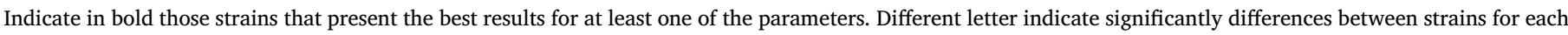
parameter.

(1056) and C. pararugosa (1231) provided the best results, with a selfaggregation of 64.43 and $63.34 \%$, respectively, which were statistically similar $(\alpha=0.05 ; \mathrm{F}=17.53 ; \mathrm{p}=0.00)$. Thus, ten strains, including 1134, 1090, 1003, 1094, 1213, 1019, 1063, 1039 and 1231 exhibited a higher auto-aggregation than the controls, with values ranging from 26.05-64.43\%. There were no significant differences among the strains despite the majority of the strains having 5 to $20 \%$ auto-aggregation.

Gil-Rodríguez, Carrascosa, and Requena (2015) found that the autoaggregation for one strain of $T$. delbrueckii was $21.4 \%$, a result comparable with our T. delbrueckii strain (1055) (19.06\%). S. cerevisiae obtained from traditional fermented foods of the Western Himalayas (Sourabh, Kanwar, \& Sharma, 2011, 2012) showed an auto-aggregation ability of about $67.54 \%$ in $20 \mathrm{~h}$. Some studies observed auto-aggregation values of around $70 \%$ in $2 \mathrm{~h}$ (Binetti, Carrasco, Reinheimer, \& Suárez, 2013; Gil-Rodríguez, Carrascosa, \& Requena, 2015). In contrast, results of the present study showed certain strains that achieved between 41 and $64 \%$ auto-aggregation, at only $30 \mathrm{~min}$ of incubation. Auto-aggregation is dependent on the strain and its cell wall composition because this property is mediated by cell-surface molecules, which 


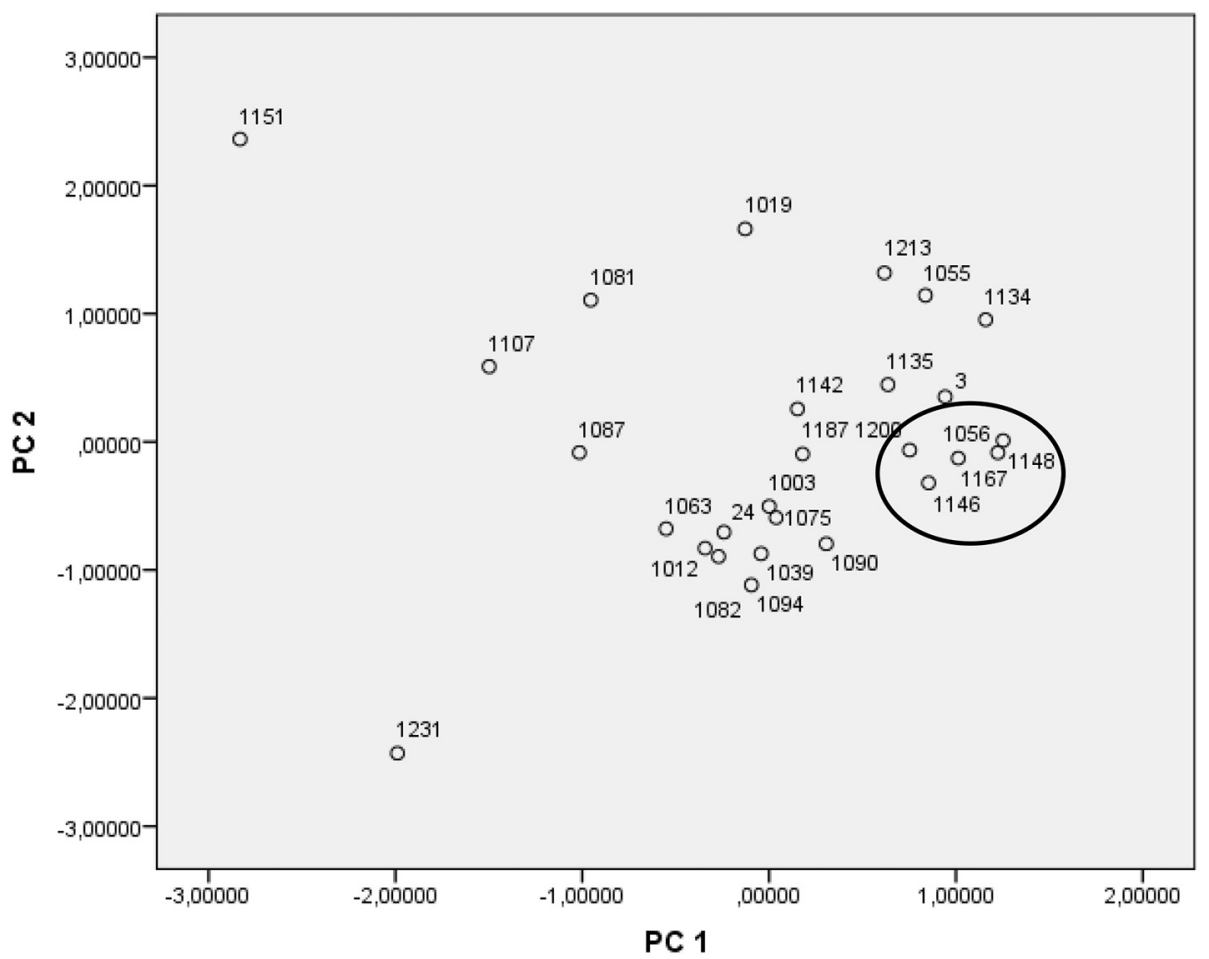

Fig. 1. Principal Component Analysis run on the fitting parameters of Warringer and Blomberg (2003) recovered for all the strains.

Table 3

Contribution of the highly correlated variables and their loadings in principal components 1 and 2 .

\begin{tabular}{lllll}
\hline $\begin{array}{l}\text { Principal } \\
\text { component }\end{array}$ & $\begin{array}{l}\text { Variance } \\
\text { explained (\%) }\end{array}$ & $\begin{array}{l}\text { Total } \\
\text { variance (\%) }\end{array}$ & $\begin{array}{l}\text { Most highly } \\
\text { correlated }\end{array}$ & Loading \\
\hline 1 & 63.08 & 63.08 & $\mathrm{G}$ & -0.89 \\
& & & $\lambda$ & -0.05 \\
2 & 25.84 & 88.92 & $\mathrm{G}$ & 0.31 \\
& & & $\mu$ & 0.02 \\
& & & OD $_{\max }$ & 0.04 \\
\hline
\end{tabular}

could explain the differences in the values found among the yeasts. The ability to self-aggregate within $30 \mathrm{~min}$, as demonstrated by certain strains in this study, could be an advantage, considering that during their passage through the gastrointestinal tract they may rapidly adhere to the mucosa before being expelled.

\subsection{Cell surface hydrophobicity}

The 25 selected strains and the controls were tested for their hydrophobicity, using two solvents, toluene and xylene. These solvents have an apolar character, and the greater the solubility of the cells in these solvents, the greater the degree of hydrophobicity.

For xylene (Table 5), the hydrophobicity values ranged from $3.16-54.16 \%$. The strains that presented the best results were $Z$. bailii (1213) and C. pararugosa (1231), with $>50 \%$ hydrophobicity. Control $1+$ showed $38.74 \%$ hydrophobicity, followed by strains $P$. kudriavzevii (1003) and T. delbrueckii (1055), possessing about $37 \%$ hydrophobicity.

For toluene (Table 5), the results ranged between 3.12 and $35.11 \%$. Five strains (1063, 1094, 1146, 1167 and 1213) showed values higher than control $2+(32.41 \%)$. Yeasts 1056, 1081, 1082, and 1090 showed about $30 \%$ hydrophobicity, which was greater than control $1+$ $(26.68 \%)$ although there were not significantly differences. These results are superior to that found for $W$. anomalus, of $25 \%$ hydrophobicity, using toluene as the solvent (García-Hernández et al., 2012).

Table 4

Auto-aggregation of each strain.

\begin{tabular}{|c|c|c|c|c|c|}
\hline Species & Strain & Auto-aggregation (\%) & Species & Strain & Auto-aggregation (\%) \\
\hline Control $1+$ & 3 & $19.81 \pm 5.86^{\mathrm{d}, \mathrm{e}, \mathrm{f}, \mathrm{g}}$ & H. osmophila & 1094 & $32.05^{2} \pm 3.25^{\mathrm{g}, \mathrm{h}, \mathrm{i}}$ \\
\hline Control $2+$ & 4 & $19.41 \pm 6.40^{\mathrm{c}, \mathrm{d}, \mathrm{e}, \mathrm{f}, \mathrm{g}}$ & C. sake & 1107 & $15.80 \pm 3.85^{\mathrm{a}, \mathrm{b}, \mathrm{c}, \mathrm{d}, \mathrm{e}, \mathrm{f}}$ \\
\hline P. kudriavzevii & 1003 & $30.36 \pm 4.90^{\mathrm{g}, \mathrm{h}, \mathrm{i}}$ & Z. fermentati & 1134 & $26.05 \pm 4.50^{\mathrm{e}, \mathrm{f}, \mathrm{g}, \mathrm{h}}$ \\
\hline M. pulcherrima & 1012 & $12.77 \pm 7.55^{\mathrm{a}, \mathrm{b}, \mathrm{c}, \mathrm{d}}$ & P. caribbica & 1135 & $7.34 \pm 5.19^{\mathrm{a}, \mathrm{b}, \mathrm{c}, \mathrm{d}}$ \\
\hline P. membranaefaciens & 1019 & $41.38 \pm 8.02^{i}$ & Z. fermentati & 1142 & $4.09 \pm 2.83^{\mathrm{a}}$ \\
\hline K. thermotolerans & 1039 & $43.11 \pm 13.57^{\mathrm{i}}$ & Lachancea sp. & 1146 & $6.06 \pm 1.50^{\mathrm{a}, \mathrm{b}, \mathrm{c}}$ \\
\hline T. delbrueckii & 1055 & $19.06 \pm 0.10^{\mathrm{b}, \mathrm{c}, \mathrm{d}, \mathrm{e}, \mathrm{f}, \mathrm{g}}$ & Lachancea sp. & 1148 & $13.97 \pm 5.39^{\mathrm{a}, \mathrm{b}, \mathrm{c}, \mathrm{d}, \mathrm{e}}$ \\
\hline H. osmophila & 1056 & $64.43 \pm 12.70^{j}$ & Candida sp. & 1151 & $5.70 \pm 3.63^{\mathrm{a}, \mathrm{b}}$ \\
\hline C. vini & 1063 & $41.62 \pm 2.05^{i}$ & K. thermotolerans & 1167 & $13.83 \pm 9.39^{\mathrm{a}, \mathrm{b}, \mathrm{c}, \mathrm{d}, \mathrm{e}}$ \\
\hline P. kudriavzevii & 1075 & $4.84 \pm 0.85^{\mathrm{a}}$ & Z. fermentati & 1187 & $9.40 \pm 2.09^{\mathrm{a}, \mathrm{b}, \mathrm{c}, \mathrm{d}}$ \\
\hline P. galeiforms & 1081 & $12.07 \pm 0.00^{\mathrm{a}, \mathrm{b}, \mathrm{c}, \mathrm{d}}$ & P. kudriavzevii & 1200 & $27.84 \pm 0.78^{\mathrm{f}, \mathrm{g}, \mathrm{h}}$ \\
\hline P. anomala & 1082 & $11.05 \pm 9.87^{\mathrm{a}, \mathrm{b}, \mathrm{c}, \mathrm{d}}$ & Z. bailii & 1213 & $34.70 \pm 2.53^{\mathrm{h}, \mathrm{i}}$ \\
\hline O. polymorpha & 1087 & $3.85 \pm 0.71^{\mathrm{a}}$ & C. pararugosa & 1231 & $63.34 \pm 11.18^{j}$ \\
\hline P. anomala & 1090 & $28.12 \pm 5.83^{f, g, h}$ & & & \\
\hline
\end{tabular}

Different letter indicate significantly differences between strains. 
Table 5

Hydrophobicity of each strain with xylene and toluene.

\begin{tabular}{|c|c|c|c|}
\hline \multirow[t]{2}{*}{ Species } & \multirow[t]{2}{*}{ Strains } & \multicolumn{2}{|l|}{ Hydrophobicity (\%) } \\
\hline & & Xylene & Toluene \\
\hline Control $1+$ & 3 & $38.74 \pm 8.37^{h}$ & $26.68 \pm 4.86^{\mathrm{c}, \mathrm{d}, \mathrm{e}, \mathrm{f}, \mathrm{g}, \mathrm{h}}$ \\
\hline Control $2+$ & 24 & $37.15 \pm 3.07^{\mathrm{h}}$ & $32.41 \pm 8.36^{\mathrm{g}, \mathrm{h}}$ \\
\hline P. kudriavzevii & 1003 & $37.90 \pm 0.92^{h}$ & $10.55 \pm 7.37^{\mathrm{a}, \mathrm{b}, \mathrm{c}}$ \\
\hline M. pulcherrima & 1012 & $15.22 \pm 4.20^{\mathrm{b}, \mathrm{c}, \mathrm{d}}$ & $15.05 \pm 5.92^{\mathrm{a}, \mathrm{b}, \mathrm{c} . \mathrm{d}, \mathrm{e}, \mathrm{f}}$ \\
\hline P. membranaefaciens & 1019 & $33.04 \pm 5.57^{\mathrm{g}, \mathrm{h}}$ & $15.66 \pm 4.37^{\mathrm{a}, \mathrm{b}, \mathrm{c}, \mathrm{d}, \mathrm{e}, \mathrm{f}, \mathrm{g}}$ \\
\hline K. thermotolerans & 1039 & $31.12 \pm 2.29^{\mathrm{f}, \mathrm{g}, \mathrm{h}}$ & $25.25 \pm 10.85^{b, c, d, e, f, g, h}$ \\
\hline T. delbrueckii & 1055 & $37.41 \pm 5.39^{h}$ & $19.34 \pm 2.66^{\mathrm{a}, \mathrm{b}, \mathrm{c}, \mathrm{d}, \mathrm{e}, \mathrm{f}, \mathrm{g}, \mathrm{h}}$ \\
\hline H. osmophila & 1056 & $31.51 \pm 7.53^{\mathrm{g}, \mathrm{h}}$ & $27.64 \pm 12.77^{\mathrm{c}, \mathrm{d}, \mathrm{e}, \mathrm{f}, \mathrm{g}, \mathrm{h}}$ \\
\hline C. vini & 1063 & $30.81 \pm 1,56^{\mathrm{f,g,h}}$ & $33.09 \pm 19.57^{\mathrm{h}}$ \\
\hline P. kudriavzevii & 1075 & $22.09 \pm 3.11^{\mathrm{d}, \mathrm{e}, \mathrm{f}}$ & $11.03 \pm 0.52^{\mathrm{a}, \mathrm{b}, \mathrm{c}}$ \\
\hline P. galeiforms & 1081 & $21.49 \pm 0.97^{\mathrm{d}, \mathrm{e}}$ & $29.60 \pm 1.80^{\mathrm{d}, \mathrm{e}, \mathrm{f}, \mathrm{g}, \mathrm{h}}$ \\
\hline P. anomala & 1082 & $23.84 \pm 1.70^{\mathrm{d}, \mathrm{e}, \mathrm{f}, \mathrm{g}}$ & $31.45 \pm 10.37^{\mathrm{e}, \mathrm{f}, \mathrm{g}, \mathrm{h}}$ \\
\hline O. polymorpha & 1087 & $10.55 \pm 2.67^{\mathrm{a}, \mathrm{b}, \mathrm{c}}$ & $5.44 \pm 0.60^{\mathrm{a}, \mathrm{b}}$ \\
\hline P. anomala & 1090 & $30.47 \pm 3.28^{\mathrm{e}, \mathrm{f}, \mathrm{g}, \mathrm{h}}$ & $31.97 \pm 7.44^{\mathrm{f,g}, \mathrm{h}}$ \\
\hline H. osmophila & 1094 & $32.52 \pm 0.03^{g, h}$ & $32.80 \pm 7.50^{\mathrm{g}, \mathrm{h}}$ \\
\hline C. sake & 1107 & $6.64 \pm 4.26^{\mathrm{a}, \mathrm{b}, \mathrm{c}}$ & $13.35 \pm 2.63^{\mathrm{a}, \mathrm{b}, \mathrm{c}, \mathrm{d}}$ \\
\hline Z. fermentati & 1134 & $10.33 \pm 0.64^{\mathrm{a}, \mathrm{b}, \mathrm{c}}$ & $8.02 \pm 2.22^{\mathrm{a}}$ \\
\hline P. caribbica & 1135 & $3.16 \pm 2.63^{\mathrm{a}}$ & $10.76 \pm 9.45^{\mathrm{a}, \mathrm{b}, \mathrm{c}}$ \\
\hline Z. fermentati & 1142 & $8.18 \pm 2.62^{\mathrm{a}, \mathrm{b}, \mathrm{c}}$ & $3.12 \pm 2.84^{\mathrm{a}}$ \\
\hline Lachancea sp. & 1146 & $6.38 \pm 1.95^{\mathrm{a}, \mathrm{b}, \mathrm{c}}$ & $33.24 \pm 5.58^{h}$ \\
\hline Lachancea sp. & 1148 & $15.75 \pm 4.58^{\mathrm{c}, \mathrm{d}}$ & $5.82 \pm 0.05^{\mathrm{a}}$ \\
\hline Candida sp. & 1151 & $6.01 \pm 2.53^{\mathrm{a}, \mathrm{b}}$ & $14.71 \pm 4.27^{\mathrm{a}, \mathrm{b}, \mathrm{c}, \mathrm{d}, \mathrm{e}}$ \\
\hline K. thermotolerans & 1167 & $10.41 \pm 0.95^{\mathrm{a}, \mathrm{b}, \mathrm{c}}$ & $3.67 \pm 15.03^{g, h}$ \\
\hline Z. fermentati & 1187 & $10.26 \pm 2.56^{\mathrm{a}, \mathrm{b}, \mathrm{c}}$ & $8.28 \pm 1.85^{\mathrm{a}}$ \\
\hline P. kudriavzevii & 1200 & $32.99 \pm 9.92^{\mathrm{g}, \mathrm{h}}$ & $11.22 \pm 2.03^{\mathrm{a}, \mathrm{b}, \mathrm{c}}$ \\
\hline Z. bailii & 1213 & $54.16 \pm 2.23^{i}$ & $35.11 \pm 12.75^{h}$ \\
\hline C. pararugosa & 1231 & $51.09 \pm 2.52^{\mathrm{i}}$ & $25.87 \pm 6.36^{\mathrm{c}, \mathrm{d}, \mathrm{e}, \mathrm{f}, \mathrm{g}, \mathrm{h}}$ \\
\hline
\end{tabular}

Different letter indicate significantly differences between strains for each variable.

Generally, as proven in the literature and in agreement with our data, more satisfactory hydrophobicity results are obtained, when xylene is employed as the solvent. Xylene is a more effective uncoupling agent than toluene and as such, is also more efficacious in depleting adenosine triphosphate. Xylene and toluene are aromatic hydrocarbons lacking proton-releasing groups. Thus, instead of a protonophoretic mechanism, attachment to specific hydrophobic sites, such as proteins, seems more likely to be responsible for the uncoupling effect of these solvents (Revilla et al., 2007).

The auto-aggregation and hydrophobicity properties are strongly linked to the ability of the microbe to adhere to the intestine. From the probiotic perspective, a high hydrophobicity of the cell surface explains why, among the yeasts, certain strains have relatively slower elimination kinetics from the gastrointestinal tract and exert different health effects. It has been observed that the hydrophobic property could be responsible for a better ability to colonize the gastrointestinal tract of germ-free mice (Martins et al., 2009).

From Fig. 2, it can be observed that yeasts with $>30 \%$ in both properties (hydrophobicity with xilene and auto-aggregation) are 1019, 1039, 1056, 1063, 1094, 1213 and 1231 and so they are suitable candidates.

\subsection{Strains selected as best according to the preliminary tests}

In order to select the strains that presented the best characteristics up to this point, PCA was applied (Fig. 3 and Table 6). Twenty-seven strains and six discriminating variables (rate, high OD, generation time, lag phase, auto-aggregation and hydrophobicity), were introduced in the analysis. It was noted that the rate and generation time were inversely proportional. Namely, a shorter doubling time resulted in a higher growth rate and, therefore, a more pronounced slope in the exponential phase. Thus, the strains of most interest were closest to the rate parameter. Again, one can see the same tendency between hydrophobicity and self-aggregation, noting greater apolarity of xylene than toluene.

Considering all of the above, the best yeasts were $H$. osmophila (1056 and 1094), Z. bailii (1213), K. thermotolerans (1039), P. anomala (1082, 1090), P. kudriavzevii $(1003,1200)$, C. vini (1063) and P. membranaefaciens (1019).

\subsection{Biofilm formation}

Biofilm formation is divided into four stages. In the initial stage, the yeasts adhere to the substrate that forms the base of the biofilm. This is followed by cell co-aggregation and colonisation. Then, the cells grow and proliferate, ultimately forming a basal layer that secures the cells (Ramage, Mowat, Jones, Williams, \& López-Ribot, 2009). Generally, adhesion is favoured where the surfaces appear to be rougher, more hydrophobic and possess a coating.

For the 10 strains selected as the best, cell viability was observed after each sample was sonicated, to separate the possible biofilms formed from the slide contained in the Falcon flasks. For all 10 strains, the viable cell count was very high, around $6 \log \mathrm{CFU} / \mathrm{cm}^{2}$, with 1063 presenting the highest $\left(6.23 \pm 0.17 \log \mathrm{CFU} / \mathrm{cm}^{2}\right)$. Strain 1039 had the lowest viability $\left(5.30 \pm 0.17 \log \mathrm{CFU} / \mathrm{cm}^{2}\right)$. However, there are no intergroup differences ( $\alpha=0.05 ; \mathrm{p}=0.02 ; \mathrm{F}=3.26)$. In comparison to these data, Perricone, Bevilacqua, Corbo, and Sinigaglia (2014) presented relatively lower viabilities $\left(2.96-4.63 \log \mathrm{CFU} / \mathrm{cm}^{2}\right)$ for yeasts from Altamura sourdough.

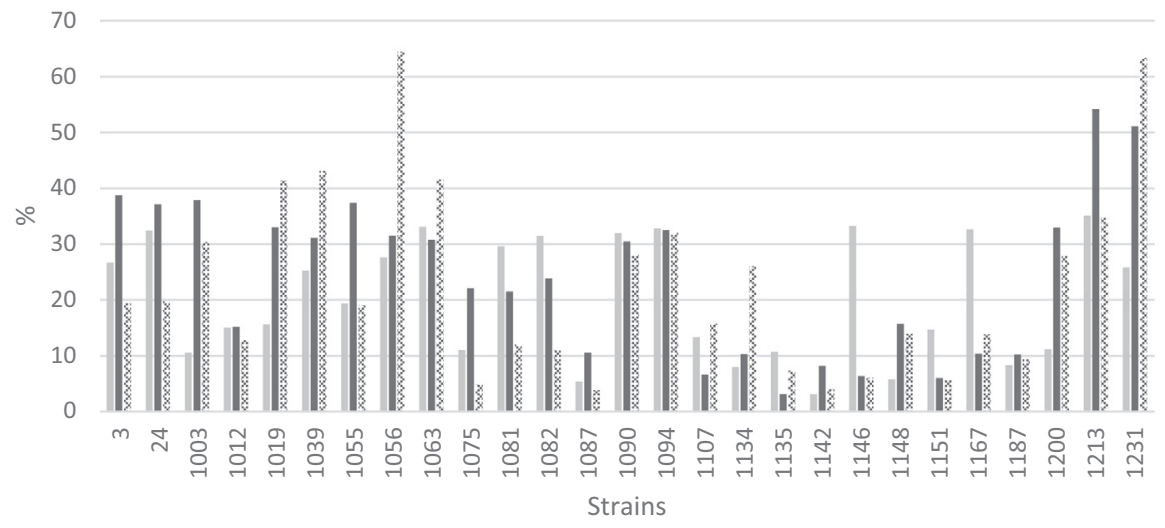

\%Hydrophobicity,TOLUENE $\quad$ \%Hydrophobicity, XYLENE \% \%AUTO-AGGREGATION

Fig. 2. Auto-aggregation and hydrophobicity percentages for the selected study strains. 


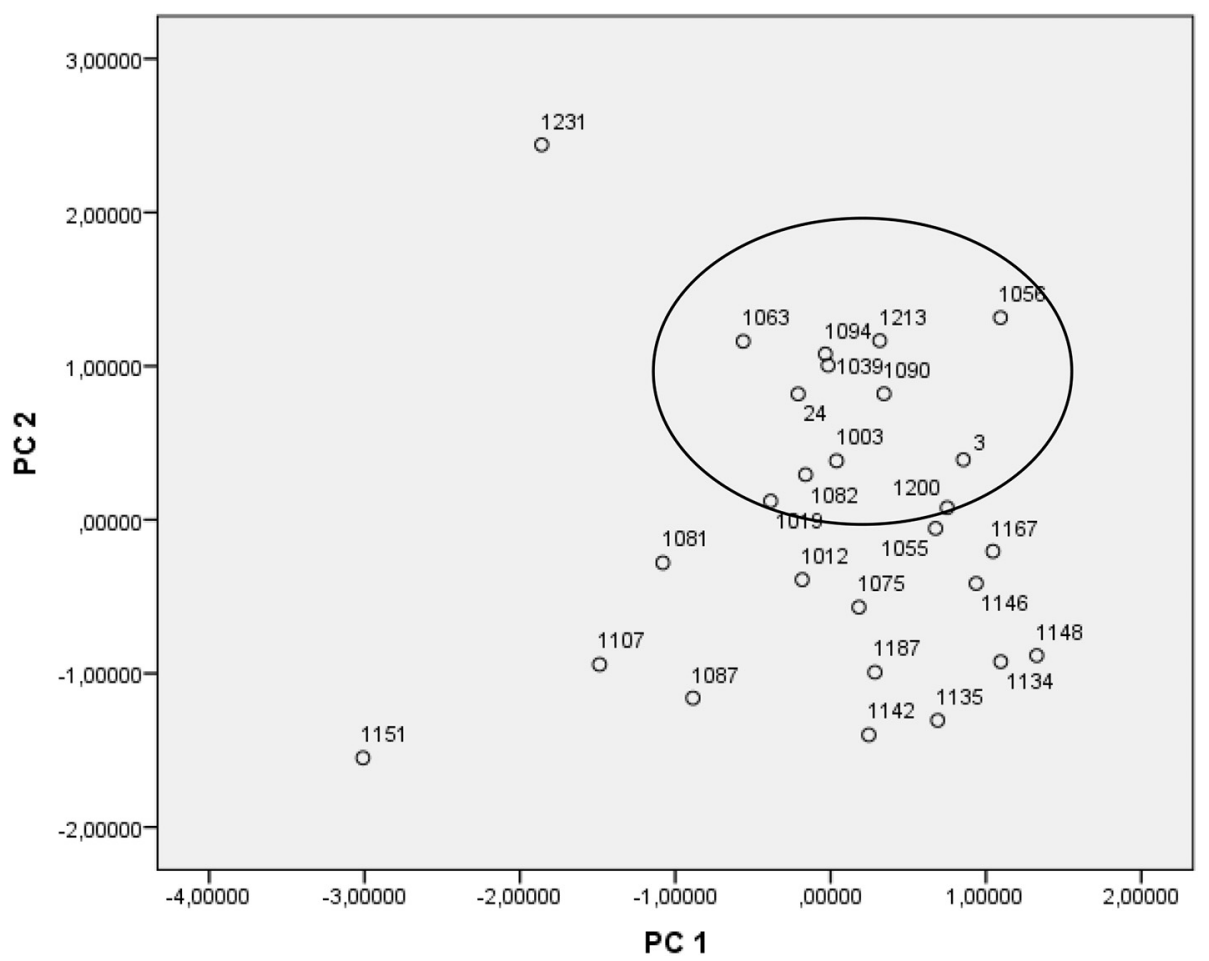

Fig. 3. Principal Component Analysis run on the fitting parameters of Warringer and Blomberg (2003) in addition to the auto-aggregation and hydrophobicity variables for the study strains.

Table 6

Contribution of the highly correlated variables and their loadings in principal components 1 and 2 .

\begin{tabular}{|c|c|c|c|c|}
\hline $\begin{array}{l}\text { Principal } \\
\text { component }\end{array}$ & $\begin{array}{l}\text { Variance } \\
\text { explained (\%) }\end{array}$ & $\begin{array}{l}\text { Total } \\
\text { variance (\%) }\end{array}$ & $\begin{array}{l}\text { Most highly } \\
\text { correlated }\end{array}$ & Loading \\
\hline \multirow[t]{6}{*}{1} & 37.86 & 37.86 & $\lambda$ & -0.14 \\
\hline & & & $\mathrm{OD}_{\max }$ & 0.90 \\
\hline & & & Auto- & -0.01 \\
\hline & & & aggregation & 0.01 \\
\hline & & & Xylene & 0.01 \\
\hline & & & Toluene & \\
\hline \multirow[t]{8}{*}{2} & 30.08 & 67.94 & $\lambda$ & -0.53 \\
\hline & & & G & -0.21 \\
\hline & & & $\mu$ & -0.02 \\
\hline & & & $\mathrm{OD}_{\max }$ & -0.02 \\
\hline & & & Auto- & 0.84 \\
\hline & & & aggregation & 0.86 \\
\hline & & & Xylene & 0.70 \\
\hline & & & Toluene & \\
\hline
\end{tabular}

\subsection{Sequential simulated digestion and its effect on viability and biofilm formation}

As shown in Fig. 4, Table 7, the cell viability and biofilm formation of the 10 most relevant strains were investigated before and after exposure to sequential simulated digestion conditions (salivary-gastricintestinal). The initial cell concentration was $8 \log \mathrm{CFU} / \mathrm{mL}$. After sequential simulated digestion, some strains, such as $P$. kudriavzevii (1003), H. osmophila $(1056,1094)$ and $P$. anomala (1090) exhibited better viability ( $>7 \log \mathrm{CFU} / \mathrm{ml}$ ) than the controls. The remaining seven strains had a viability around $6 \log \mathrm{CFU} / \mathrm{mL}$. No significant intergroup differences were observed $(\alpha=0.05 ; \mathrm{p}=0.005 ; \mathrm{F}=4.90)$. Regarding biofilm formation, strains 1003, 1019 and 1094 showed the best results but the values were slightly lower than control $1+(S$. cerevisiae strain UCLM 3 ).

It is noted that in contrast to other strains, the biofilm forming ability of the commercial yeast ( $S$. cerevisiae var. boulardii) was not

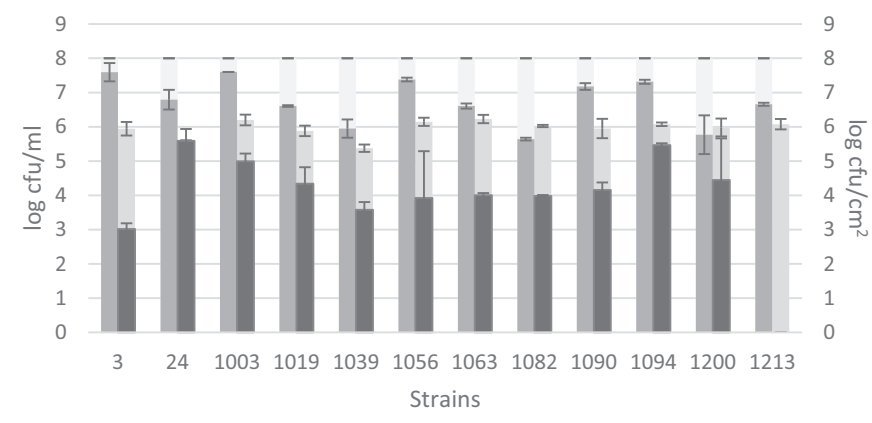

Viability before the gastrointestinal tract (log cfu/ml)

- Formation of biofilm before gastrointestinal tract $(\log \mathrm{cfu} / \mathrm{cm} 2)$

Viability after the gastrointestinal tract (log cfu/ml)

- Formation of biofilm after gastrointestinal tract (log cfu/cm2)

Fig. 4. Viability and biofilm formation before and after gastrointestinal tract by each of the strains selected as best according to gastrointestinal resistance, autoaggregation and hydrophobicity tests.

affected by the digestive conditions. Nevertheless, 1003 and 1094, lost just 19 and 10\% biofilm-forming ability, respectively, and two other strains (1019 and 1200) showed a loss of $<30 \%$. Besides control $1+$, none of the strains exceeded a viability loss of $40 \%$, except strain 1213 , which after simulated digestion, was not able to form a biofilm.

\section{Conclusions}

In this paper, a step-by-step approach was used to characterise the probiotic potential of certain non-Saccharomyces yeasts isolated from food ecosystems. From 215 isolates, 108 were identified as different strains by RAPD analysis. Some strains were distinguished for their optimal growth parameters, such as Lachancea sp. (1146 and 1148), $H$. osmophila (1056), K. thermotolerans (1167) and P. kudriavzevii (1200), 
Table 7

Loss of viability and biofilm formation capability after simulation of gastrointestinal conditions.

\begin{tabular}{llll}
\hline Species & Strain & $\begin{array}{l}\text { Loss viability after } \\
\text { tract (\%) }\end{array}$ & $\begin{array}{l}\text { Loss biofilm formation } \\
\text { capability (\%) }\end{array}$ \\
\hline Control 1+ & 3 & $5 \pm 0.66^{\mathrm{a}}$ & $48 \pm 0.26^{\mathrm{d}}$ \\
Control 2+ & 24 & $15 \pm 5.07^{\mathrm{bcd}}$ & $0 \pm 0.27^{\mathrm{a}}$ \\
P. kudriavzevii & 1003 & $5 \pm 0.10^{\mathrm{a}}$ & $19 \pm 0.22^{\mathrm{bc}}$ \\
P. membranaefaciens & 1019 & $17 \pm 0.42^{\mathrm{d}}$ & $26 \pm 0.35^{\mathrm{bcd}}$ \\
K. thermotolerans & 1039 & $26^{\mathrm{c}} \pm 4.72^{\mathrm{e}}$ & $33 \pm 0.19^{\mathrm{cd}}$ \\
H. osmophila & 1056 & $8 \pm 0.96^{\mathrm{ab}}$ & $36 \pm 0.77^{\mathrm{cd}}$ \\
C. vini & 1063 & $17 \pm 1.32^{\mathrm{d}}$ & $36 \pm 0.12^{\mathrm{cd}}$ \\
P. anomala & 1082 & $29 \pm 0.70^{\mathrm{e}}$ & $34 \pm 0.04^{\mathrm{cd}}$ \\
P. anomala & 1090 & $10 \pm 1.72^{\mathrm{abcd}}$ & $30 \pm 0.31^{\mathrm{bcd}}$ \\
H. osmophila & 1094 & $9 \pm 1.04^{\mathrm{abc}}$ & $10 \pm 0.06^{\mathrm{ab}}$ \\
P. kudriavzevii & 1200 & $28 \pm 9.99^{\mathrm{e}}$ & $26 \pm 0.79 \mathrm{~b}^{\mathrm{cd}}$ \\
Z. bailii & 1213 & $17 \pm 0.77^{\mathrm{cd}}$ & $100 \pm 0.11^{\mathrm{e}}$ \\
\hline
\end{tabular}

Different letter indicate significantly differences between strains for each variable.

which offered better results than the reference probiotics strains used as the controls. Furthermore, many strains were tolerant to simulated digestive conditions, an essential property for a probiotic. In addition, strain 1056 was noted for its aggregation capacity, followed by $C$. pararugosa (1231), which, in turn, was noted for its hydrophobic capacity. In terms of biofilm formation, $H$. osmophila (1094), 1200, P. kudriavzevii (1003) and P. membranaefaciens (1019) were the most promising.

These results suggest that various non-Saccharomyces yeast species harbour strains with probiotic potential, although there is no one with optimal results together. Thus, future studies will be done for the final selection that include the GRASS character of the selected strains among others. Moreover, the strains with multifunctional potentials isolated in this study, could be used to produce probiotic products (foods and drugs). This might be a solution to the steadily increasing demands for these products.

\section{Acknowledgements}

The authors wish to express their gratitude to Junta de Comunidades de Castilla La-Mancha for funding this research, (Ref: CCM17-PIC-322).

\section{References}

Andrighetto, C., Psomas, E., Tzanetakis, N., Suzzi, G., \& Lombardi, A. (2000). Randomly amplified polymorphic DNA (RAPD) PCR for the identification of yeasts isolated from dairy products. Letters in Applied Microbiology, 30, 5-9.

Arévalo-Villena, M., Fernández-Pacheco, P., Castillo, N., Bevilacqua, A., \& Briones, A. (2018). Probiotic yeast. Set up of a method for screening. LWT-Food Science \& Technology, 89, 657-665.

Armando, M. R., Pizzolitto, R. P., Dogi, C. A., Cristofolini, A., Merkis, C., Poloni, V., Cavaglieri, L. R. (2012). Adsorption of ochratoxin a and zearalenone by potential probiotic Saccharomyces cerevisiae strains and its relation with cell wall thickness. Journal of Applied Microbiology, 113, 256-264.

Barrajón, N., Arévalo-Villena, M., \& Briones, A. (2009). Ecological study of wine yeast in inoculated vats from La Mancha region. Food Control, 20, 778-783.

Bautista-Gallego, J., Arroyo-López, F. N., Rantsiou, K., Jiménez-Díaz, R., GarridoFernández, A., \& Cocolin, L. (2013). Screening of lactic acid bacteria isolated from fermented table olives with probiotic potential. Food Research International, 50, 135-142.

Binetti, A., Carrasco, M., Reinheimer, J., \& Suárez, V. (2013). Yeasts from autochthonal cheese starters: Technological and functional properties. Journal of Applied Microbiology, 115, 434-444.

Blehaut, H., Massot, J., Elmer, G. W., \& Levy, R. H. (1989). Disposition kinetics of Saccharomyces boulardii in man and rat. Biopharmaceutics \& Drug Disposition, 10, 353-364.

Boris, S., Suárez, J. E., \& Barbés, C. (1997). Characterization of the aggregation promoting factor from Lactobacillus gasseri a vaginal isolate. Journal of Applied Microbiology, 83, 413-420.

Chelliah, R., Ramakrishnan, S. R., Prabhu, P. R., \& Antony, U. (2016). Evaluation of antimicrobial activity and probiotic properties of wild-strain Pichia kudriavzevii isolated from frozen idli batter. Yeast, 33, 385-401.
Corte, L., Lattanzi, M., Buzzini, P., Bolano, A., Fatichenti, F., \& Cardinali, G. (2005). Use of RAPD and killer toxin sensitivity in Saccharomyces cerevisiae strain typing. Journal of Applied Microbiology, 99, 609-617.

Czerucka, D., \& Rampal, P. (2002). Experimental effects of Saccharomyces boulardii on diarrheal pathogens. Microbes and Infection, 4, 733-739.

Dunne, C., O'Mahony, L., Murphy, L., Thornton, G., Morrissey, D., O'Halloran, S., .. Collins, J. K. (2001). In vitro selection criteria for probiotic bacteria of human origin: Correlation with in vivo findings. The American Journal of Clinical Nutrition, 73, 386S-392S.

García-Hernández, Y., Rodríguez, Z., Brandão, L. R., Rosa, C. A., Nicoli, J. R., Iglesias, A. E., ... Halaihel, N. (2012). Identification and in vitro screening of avian yeasts for use as probiotic. Research in Veterinary Science, 93, 798-802.

Gil-Rodríguez, A. M., Carrascosa, A. V., \& Requena, T. (2015). Yeasts in foods and beverages: in vitro characterisation of probiotic traits. LWT Food Science and Technology, 64, 1156-1162.

Grando, M. S., Ubeda, J., \& Briones, A. I. (1994). RAPD analysis of wine Saccharomyces cerevisiae strains differentiated by pulsed field gel electrophoresis. Biotechnology Techniques, 8, 557-560.

Guillamón, J. M., \& Barrio, E. (2017). Genetic polymorphism in wine yeasts: Mechanisms and methods for its detection. Frontiers in Microbiology, 8

Hill, C., Guarner, F., Gibson, G. R., Merenstein, D. J., Pot, B., Morelli, L., ... Sanders, M. E. (2014). Expert consensus document: The international scientific Association for Probiotics and Prebiotics consensus statement on the scope and appropriate use of the term probiotic. Nature Reviews Gastroenterology and Hepatology, 11, 506-514.

Klein, S. M., Elmer, G. W., McFarland, L. V., Surawicz, C. M., \& Levy, R. H. (1993). Recovery and elimination of the biotherapeutic agent, Saccharomyces boulardii, in healthy human volunteers. Pharmaceutical Research, 10, 1615-1619.

Kos, B., Šušković, J., Goreta, J., \& Matošić, S. (2000). Effect of protectors on the viability of Lactobacillus acidophilus M92 in simulated gastrointestinal conditions. Food Technology and Biotechnology, 38, 121-127.

Kourelis, A., Kotzamanidis, C., Litopoulou-Tzanetaki, E., Scouras, Z. G., Tzanetakis, N., \& Yiangou, M. (2010). Preliminary probiotic selection of dairy and human yeast strains. Journal of Biological Research-Thessaloniki, 13, 93-104.

Martins, F. S., Silva, A. A., Vieira, A. T., Barbosa, F. H. F., Arantes, R. M. E., Teixeira, M. M., \& Nicoli, J. R. (2009). Comparative study of Bifidobacterium animalis, Escherichia coli, Lactobacillus casei and Saccharomyces boulardii probiotic properties. Archives of Microbiology, 191, 623-630.

Ortiz, M., Barrajón, N., Aalver-Baffi, M., Arévalo-Villena, M., \& Briones, A. (2013). Spontaneous must fermentation: Identification and biotechnological properties of wine yeasts. LWT- Food Science and Technology, 50, 371-377.

Padilla, B., Manzanares, P., \& Belloch, C. (2014). Yeast species and genetic heterogeneity within Debaryomyces hansenii along the ripening process of traditional ewes' and goats' cheeses. Food Microbiology, 38, 160-166.

Pedersen, L. L., Owusu-Kwarteng, J., Thorsen, L., \& Jespersen, L. (2012). Biodiversity and probiotic potential of yeasts isolated from Fura, a west African spontaneously fermented cereal. International Journal of Food Microbiology, 159, 144-151.

Pennacchia, C., Blaiotta, G., Pepe, O., \& Villani, F. (2008). Isolation of Saccharomyces cerevisiae strains from different food matrices and their preliminary selection for a potential use as probiotics. Journal of Applied Microbiology, 105, 1919-1928.

Pérez-Sotelo, L. S., Talavera-Rojas, M., Monroy-Salazar, H. G., Lagunas-Bernabé, S., Cuarón-Ibargüengoytia, J. A., Jiménez, R. M. D. O., \& Vázquez-Chagoyán, J. C. (2005). In vitro evaluation of the binding capacity of Saccharomyces cerevisiae Sc47 to adhere to the wall of Salmonella spp. Revista Latinoamericana de Microbiologia, 47, 70-75.

Perricone, M., Bevilacqua, A., Corbo, M. R., \& Sinigaglia, M. (2014). Technological characterization and probiotic traits of yeasts isolated from Altamura sourdough to select promising microorganisms as functional starter cultures for cereal-based products. Food Microbiology, 38, 26-35.

Pizzolitto, R. P., Armando, M. R., Combina, M., Cavaglieri, L. R., Dalcero, A. M., \& Salvano, M. A. (2012). Evaluation of Saccharomyces cerevisiae strains as probiotic agent with aflatoxin $B_{1}$ adsorption ability for use in poultry feedstuffs. Journal of Environmental Science and Health, Part B Pesticides, Food Contaminants, and Agricultural Wastes, 47, 933-941.

Priya, A. J., Vijayalakshmi, S. P., \& Raichur, A. M. (2011). Enhanced survival of probiotic Lactobacillus acidophilus by encapsulation with nanostructured polyelectrolyte layers through layer-by-layer approach. Journal of Agricultural and Food Chemistry, 59, $11838-11845$.

Psani, M., \& Kotzekidou, P. (2006). Technological characteristics of yeast strains and their potential as starter adjuncts in Greek-style black olive fermentation. World Journal of Microbiology and Biotechnology, 22, 1329-1336.

Ramage, G., Mowat, E., Jones, B., Williams, C., \& López-Ribot, J. (2009). Our current understanding of fungal biofilms. Critical Reviews in Microbiology, 35, 340-355.

Revilla, A. S., Pestana, C. R., Pardo-Andreu, G. L., Santos, A. C., Uyemura, S. A., Gonzales, M. E., \& Curti, C. (2007). Potential toxicity of toluene and xylene evoked by mitochondrial uncoupling. Toxicology In Vitro, 21, 782-788.

Romo Sánchez, S., Alves Baffi, M., Arévalo, M., Úbeda, J., \& Briones, A. (2010). Yeast biodiversity from oleic ecosystems: Study of their biotechnological properties. Food Microbiology, 27(4), 87-492.

Silva, T., Reto, M., Sol, M., Peito, A., Peres, C. M., Peres, C., \& Malcata, F. X. (2011). Characterization of yeast from Portuguese brined olives, with a focus on their potentially probiotic behavior. LWT - Food Science and Technology, 44, 1349-1354.

Sourabh, A., Kanwar, S. S., \& Sharma, O. P. (2011). Screening of indigenous yeast isolates obtained from traditional fermented foods of western Himalayas for probiotic attributes. Journal of Yeast and Fungi Research, 2, 117-126.

Sourabh, A., Kanwar, S. S., \& Sharma, O. P. (2012). In vitro characterization of Saccharomyces cerevisiae HM535662 obtained from an indigenous fermented food 
"Bhaturu" of western Himalayas. African Journal of Biotechnology, 11, 11447-11454. Speranza, B., Corbo, M. R., \& Sinigaglia, M. (2011). Effects of nutritional and environmental conditions on Salmonella sp. biofilm formation. Journal of Food Science, 76, M12-M16.

Suzzi, G., Lombardi, A., Lanorte, M. T., Caruso, M., Andrighetto, C., \& Gardini, F. (2000). Phenotypic and genotypic diversity of yeasts isolated from water-buffalo mozzarella cheese. Journal of Applied Microbiology, 88, 117-123.

Úbeda, J., Maldonado Gil, M., Chiva, R., Guillamón, J. M., \& Briones, A. (2014)
Biodiversity of non-saccharomyces yeasts in distilleries of the La Mancha region (Spain). FEMS Yeast Research, 14(4), 663-673.

Vine, N. G., Leukes, W. D., Kaiser, H., Daya, S., Baxter, J., \& Hecht, T. (2004). Competition for attachment of aquaculture candidate probiotic and pathogenic bacteria on fish intestinal mucus. Journal of Fish Diseases, 27, 319-326.

Warringer, J., \& Blomberg, A. (2003). Automated screening in environmental arrays allows analysis of quantitative phenotypic profiles in Saccharomyces cerevisiae. Yeast, 20, 53-67. 